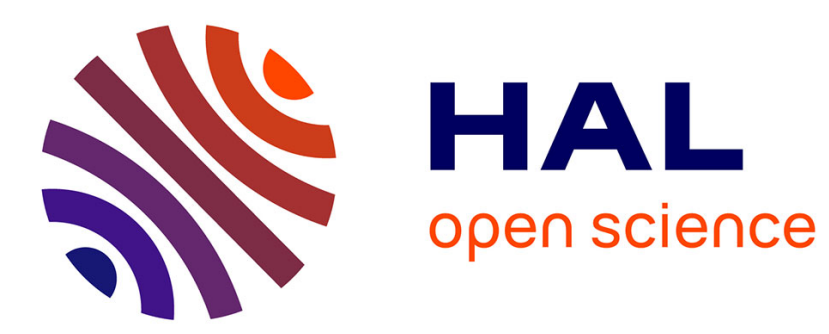

\title{
New Chalicotheriidae (Perissodactyla, Mammalia) from the late Miocene of Bulgaria.
}

Denis Geraads, Nikolaï Spassov, Dimitar Kovachev

\section{To cite this version:}

Denis Geraads, Nikolaï Spassov, Dimitar Kovachev. New Chalicotheriidae (Perissodactyla, Mammalia) from the late Miocene of Bulgaria.. Journal of Vertebrate Paleontology, 2001, 21 (3), pp.596-606. halshs-00067712

\section{HAL Id: halshs-00067712 \\ https://shs.hal.science/halshs-00067712}

Submitted on 10 May 2006

HAL is a multi-disciplinary open access archive for the deposit and dissemination of scientific research documents, whether they are published or not. The documents may come from teaching and research institutions in France or abroad, or from public or private research centers.
L'archive ouverte pluridisciplinaire HAL, est destinée au dépôt et à la diffusion de documents scientifiques de niveau recherche, publiés ou non, émanant des établissements d'enseignement et de recherche français ou étrangers, des laboratoires publics ou privés. 
New ChalicotheriIdae (Perissodactyla, Mammalia) From the Late Miocene of BULGARIA

\section{Denis GeraAds ${ }^{1}$, NiKOlä̈ Spassov ${ }^{2}$ and Dimitar KovacheV ${ }^{3}$ \\ ${ }^{1}$ UPR 2147 CNRS, 44 rue de l'Amiral Mouchez, 75014 PARIS, France;}

${ }^{2}$ National Museum of Natural History, 1, Tsar Osvoboditel blvd, 1000 SOFIA, Bulgaria;

${ }^{3}$ Museum of Paleontology (Branch of the National Museum of Natural History, Sofia), ASSENOVGRAD, Bulgaria

Running title: Geraads et al.-Chalicotheriidae from Bulgaria 
ABSTRACT-Few fossils have been described from the very rich localities of Kalimantsi in southwestern Bulgaria, and none from Hadjidimovo, in the same area. These deposits have produced one of the best collections of Chalicotheriidae from the late Miocene of Europe, increasing the diversity of the family, and providing the first definite evidence of the cooccurrence of both subfamilies, Chalicotheriinae and Schizotheriinae. The milk dentition of Ancylotherium is described for the first time; it confirms that this genus is close to, but different from, the American Tylocephalonyx. A chalicotheriine skull from Kalimantsi, with a characteristic tooth morphology, is referred to a new genus and species, Kalimantsia bulgarica. A revision of the taxonomy and systematics of European Chalicotheriinae leads us to discard "Macrotherium", which is a junior synonym of $\underline{\text { Chalicotherium, to revive Anisodon }}$ Lartet for middle Miocene forms, and to suggest the extension of Kalimantsia into the latest Miocene of the Balkans. 


\section{INTRODUCTION}

The fossil record of the family Chalicotheriidae in the Old World is rather sparse, and Chalicotheres are seldom common in any given locality. Few sites have yielded more than a handful of specimens, even during the second half of the Miocene, when the group reached its climax. This scarcity combined with the uniformity of Chalicothere dental morphology has long prevented the recognition of more than two genera in the late Miocene of the Old World, Chalicotherium and Ancylotherium (e.g. Heissig, 1998), belonging to the two known subfamilies, Chalicotheriinae and Schizotheriinae. A recent revision, however, led Bonis et al.

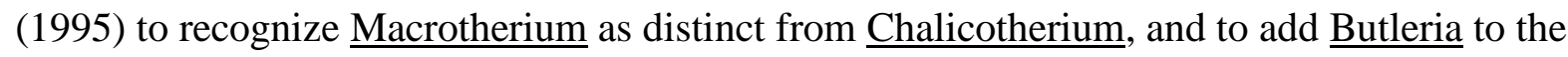
list of genera.

New material from Bulgaria described here further increases the diversity of the family. It was collected by one of us (D.K.) in the southwestern part of Bulgaria, at two sites (Fig.1) already mentioned in the literature (Nikolov, 1985) but from where only a few fossils have been described in detail (Bakalov and Nikolov, 1962).

The fossiliferous site of Kalimantsi belongs to the Kalimantsi Formation, Sandanski Graben (Kojumdgieva et al., 1982). The site includes several localities, but most of their faunas are still unpublished. The age of the lowest locality could be equivalent to the Vallesian of the western European Mammalian biochronology, the others being of early to middle Turolian age (MN 11/12; Nikolov, 1985; Tzankov et al., 1999). The locality Kalimantsi-Pehtsata (Kovachev, 1988) is one of them. It has yielded, in addition to the Chalicotheres described below: Indarctos bakalovi, aff Hyaenictitherium sp., Helladotherium duvernoyi, Bohlinia attica, Gazella sp. Other fossils from this locality have yet to be identified, but other localities in the same part of the Kalimantsi Formation yielded Hipparion $\underline{\text { mediterraneum, }} \underline{\text { H. matthewi, }}$ cf Tragoportax sp. and Palaeoreas $\mathrm{cf} \underline{\text { lindermayeri}}$. 
Hadjidimovo is close to Locality 82 of Nikolov (1985). It has a fauna (unpublished) similar to, but probably somewhat earlier than, that of Pikermi in Greece and could correspond to the first half of the MN 12 European biozone (Spassov, 1999 and in press). Three fossiliferous spots are known, but all the Chalicotheriidae described below come from Hadjidimovo-1 (= Hadjidimovo-Girizite), a single bone concentration. Among the most significant taxa of the long faunal list are: Mesopithecus $\mathrm{cf}$ delsoni, $\underline{\text { Hyaenotherium } \mathrm{cf}} \underline{\text { wongii }}$, $\underline{\text { Miohyaenotherium bessarabicum, Paramachairodus orientalis, }}$ Ceratotherium neumayri,

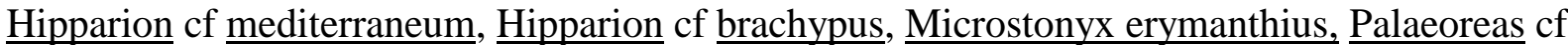
lindermayeri, Tragoportax cf amalthea, aff Tragoportax sp., Oioceros sp., Gazella sp.

Both localities certainly sampled an open environment, perhaps more so at Hadjidimovo because of the relatively poor diversity of the Bovid fauna, when the huge number of collected specimens (minimum number of Bovid individuals greater than 300 ) is taken into account.

\author{
SYSTEMATIC PALEONTOLOGY \\ Class Mammalia \\ Order Perissodactyla \\ Family Chalicotheriidae \\ Sub-family Chalicotheriinae
}

Kalimantsia gen. nov.

Type species--Kalimantsia bulgarica sp. nov.

Etymology--From Kalimantsi, type locality of the type species. Feminine.

Diagnosis--That of the type and only known species.

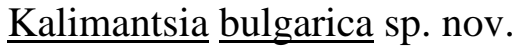

Holotype--An almost complete but transversely crushed skull, K631 in the Museum of Paleontology (Branch of the NMNH. - Sofia), Assenovgrad, Bulgaria (Fig. 2A-B). 
Type Locality--Kalimantsi-Pehtsata, middle part of the Kalimantsi formation, Sandanski Graben, Bulgaria (MN11/12 ?).

Diagnosis--A Chalicothere with a skull that is rather high, with a very long cerebral part, and a moderately shortened muzzle. P3 and P4 with complete internal cingulum. P3 broad, with an isolated protocone. Molars much longer than wide, with a short protoloph, but a long, well developed crescent-shaped hypocone.

Description--The holotype skull lacks the nasal area, occipital condyles, and zygomatic arches. No details are visible in the basicranial area. Most of the teeth, except P2, are well preserved, either on the right or left side, and moderately worn. The skull is transversely crushed, but longitudinal proportions have not been altered.

The most noticeable feature of Kalimantsia bulgarica is the lengthening of the postorbital part, strongly contrasting with the short muzzle (see measurements, Table 1). The anterior border of the orbit is above the middle of M2. The infraorbital foramen is not very close to the orbit and it is unlikely that the (incomplete) nasomaxillary area was much reduced, although the outline of the frontal shows that the snout was not extremely deep. There is no antorbital depression.

The orbit is rather square, with an anterosuperior angle underlined by a vertical rim along its border. The lachrymal foramen opens within the orbit, rather far from its border. The postorbital process is weak. There is a groove running to the optic foramen, but no pterygoid gap, but it is impossible to tell whether there was an alisphenoid canal.

Crushing has increased the sharpness of the sagittal crest, but it was certainly welldefined and long. This feature may indicate that the skull from Kalimantsi is male, chalicothere skulls being sexually dimorphic (Coombs, 1975).

The occipital area is too damaged to be described, but it was certainly high. 
Lengthening of the skull is also reflected in the posterior extension of the palate behind the M3s, with the choanae opening behind these teeth. They are divided in the sagittal plane by a thick vomerine wall which extends posteriorly to the basisphenoid. This sagittal wall is a constant feature of all Chalicotheriinae.

The teeth of the holotype (Fig.3A-C) are moderately to heavily worn. P2 is very incomplete, but enough is preserved to see that it was much narrower than P3.

P3 is relatively well preserved. It is very broad, being only a little narrower than P4 but much shorter (Fig. 4). The labial cusps are well worn. The metacone sends a very short metaloph lingually, but this crest does not even reach the base of the protocone. The latter cusp is long, and bifurcated posteriorly, but each arm is very short. The protocone also sends a low crest mesiolabially, parallel to the cingular ridge, but this crest fails to meet the incipient protoloph issued from the paracone. As on $\mathrm{P} 4$, the cingulum is continuous all around the lingual side. The complete isolation of the $\mathrm{P} 3$ protocone of $\underline{\mathrm{K}}$. bulgarica is a rare feature among Old World chalicotheres.

P4 (Fig.3A) is better preserved and less worn on the right side. The labial cusps are poorly defined. They both send a crest towards the protocone, the top of which is only reached by the metaloph, so that the central valley would open mesio-lingually, were it not blocked by a strong cingular ridge (which is weaker on the left P4). This tooth is rather different from an upper premolar from Kalimantsi (M630) figured by Nikolov (1975, pl.1, fig.2), which is broader and shorter, and has a very low metaloph and no protoloph. From its size and Wshaped ectoloph in labial view, M630 is more likely to be a P4, but its proportions and morphology are more like those of the P3 of Kalimantsia. It cannot be unambiguously referred to Kalimantsia, but does not either provide definite evidence of another taxon at Kalimantsi.

M1 is too worn to be described. 
M2 is but little different from M3, and both teeth can be described together (Fig.3B). Chalicothere molars are quite uniform in morphology, and the teeth of $\underline{\mathrm{K}}$. bulgarica share the same general pattern with other Chalicotheriinae, but their proportions (Fig.5), and the morphology of the hypocone are characteristic. M2, and especially M3, are much longer than broad; the great length of M3 is mainly achieved by the second lobe, which is less, or much less reduced than in other taxa. The posterior half of the ectoloph is rather long and its distal part is parallel to the long axis of the tooth. The hypocone is crescent-shaped, with a strong posterior arm, posterolabially recurved, enclosing a postfossette. The protoloph is very short, not rising onto the protocone

Comparisons--Only a few comparable skulls are known in the middle and late Miocene of the Old World. These are:

1) the skull from the middle Miocene of Sansan, France, illustrated by Blainville (1849: pls.3 and 8; also Bonis \& al. 1995: pl.5, fig.2). This skull was referred by Bonis et al. (1995) to Macrotherium grande (Blainville, 1849) but thought by them to be lost. It was recently found (unnumbered) in the collections of the Institut de Paléontologie, Muséum National d'Histoire Naturelle, Paris (MNHNP), and made available to D.G. by P.Tassy. The generic name

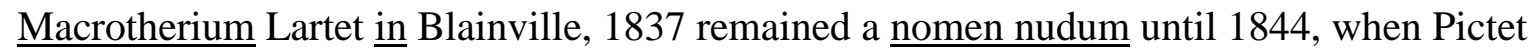
named the first species referred to this genus, Macrotherium giganteum. However, the lectotype of this species (Butler, 1965: 168) belongs to Chalicotherium goldfussi Kaup, 1833 and the generic name $\underline{\text { Macrotherium }}$ is therefore a junior synonym of $\underline{\text { Chalicotherium Kaup, }}$ 1833. The valid generic name for the middle Miocene species grande is Anisodon Lartet, 1851.

2) the holotype skull of Chalicotherium brevirostris Colbert, 1934 (AMNH 26518) from the middle Miocene Tung Gur Formation of Mongolia. 
3) the skull (Lgr 1065 in Musée Guimet, Lyons) from La Grive, France (probably of late middle Miocene age), type of Macrotherium grande rhodanicum Depéret, 1892, but referred by Bonis et al. (1995) to Chalicotherium goldfussi.

4) the holotype skull of Macrotherium macedonicum Bonis et al., 1995 (DKO 234 in the Department of Geology, University of Thessaloniki, Greece), from the latest Miocene of Dytiko, Northern Greece (a locality geographically very close to Kalimantsi).

L.de Bonis and G.Bouvrain kindly made casts of these 3 skulls available to D.G.

The Bulgarian material can also be compared with that of the middle Miocene of Neudorf (Slovakia) beautifully described and illustrated by Zapfe (1979) as Chalicotherium grande.

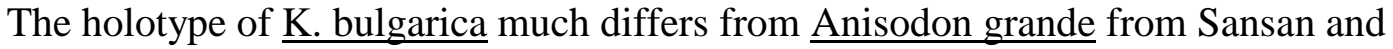
Neudorf by its skull which is high and narrow rather than broad and low, the presence of a sagittal crest (if this is not just a sexual character), and its reduced muzzle without antorbital

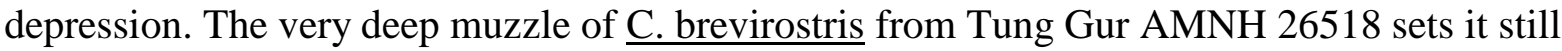
further from the Bulgarian species.

The holotype of $\underline{\mathrm{K}}$. bulgarica resembles that of " $\underline{\mathrm{M}}$." macedonicum in the shape of orbit and general proportions of the skull, but the muzzle is less shortened, without the strong upward curving of the tooth-row anteriorly, and the pterygoid gap of the Greek form is lacking.

Upper molars of upper Miocene Chalicotheriines, including Kalimantsia, differ from those of middle Miocene ones by the shortness of the protoloph, which does not rise onto the protocone. Besides this, the teeth of $\underline{\mathrm{K}}$. bulgarica can readily be distinguished from all of them by their great length (Fig.5), and by the morphology of the hypocone. All other Chalicotheriinae have M3s which are only slightly longer than broad, or even shorter than broad, the second lobe being more reduced. In $\underline{\mathrm{K}}$. bulgarica, the posterior half of the ectoloph 
is less shortened and less oblique in occlusal view (in respect to antero-posterior axis) than in all other species (the specimens from La Grive (Lgr 1065) and Dytiko (DKO 234) being the most different, with an ectoloph which is almost transversely directed). In $\underline{\text {. goldfussi, the }}$ species most commonly mentioned in the upper Miocene of Europe, the protocone is very large and occupies most of the lingual part of the crown, while the posterior part is much reduced (Zapfe, 1979: fig.8b; Symeonidis, 1973: pl.24). By the great length of its molars,

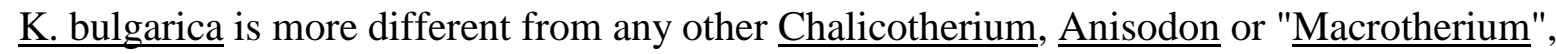
than any two specimens of the last three genera are from each other. The specimen most similar to K. bulgarica is the maxilla from Nikolsburg figured by Abel (1922: fig.108), and

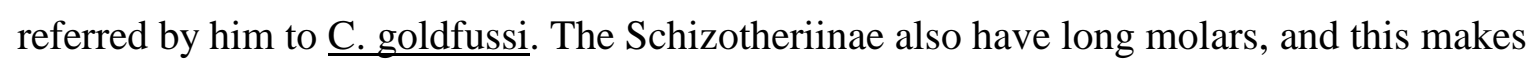
primitive members of this sub-family, such as the lower Miocene Metaschizotherium wetzleri (Fejfar et al., 1999) to resemble superficially K. bulgarica, but the former species has a long protoloph with a distinct paraconule, quite unlike the short protoloph of Kalimantsia.

In all other specimens, the hypocone is nothing more than the lingual end of the metaloph, and is not a distinct cusp; thus, it is much more reduced than in $\underline{\mathrm{K} \text {. bulgarica. }}$

Discussion--Bonis et al. (1995) reached the conclusion that differences in skull proportions make it impossible for a single genus to accommodate all species of Chalicotherium s.l., as was previously accepted. We concur with this opinion, but assigning these species to distinct genera is not easy.

First, there are some differences between the chalicothere of Sansan and that of Neudorf, although all authors have included them in the species $\underline{C \text {. grande }}$ (or Macrotherium grande). The occipital is extremely low and broad at Neudorf, but the rear part of the skull is not shortened. At Sansan, the occipital is not so low, and its upper part not so broad, but the cranial basis is much shortened. Specific identity of the chalicotheres in both sites is, in our opinion, doubtful. 
Still, they can be included in the same genus Anisodon, which shows the following differences from the Kalimantsi skull:

1) the occipital is low and broad;

2) the temporal fossa is short, at least at Sansan (it is unknown at Neudorf);

3) the sagittal crest is short or absent (a difference of doubtful taxonomic significance);

4) the face is long, the muzzle is deep, with the tooth-row diverging forwards from the upper skull profile;

5) the lingual cingulum of P3 and P4 is reduced; the latter tooth is much broader than the former, although not much longer;

6) molars have a long protoloph;

7) molars are wide in respect to their length.

Such a large set of differences prevent the inclusion of the Kalimantsi skull K608 in

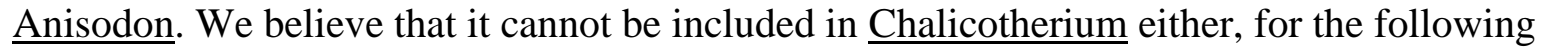
reasons:

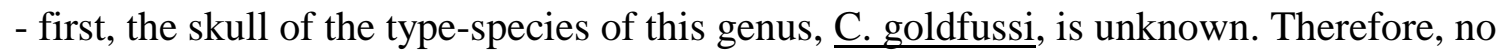
other species (indeed, very few fossils) can be confidently included in the same genus; - secondly, C. goldfussi (Kaup, 1833; Symeonidis, 1973; Zapfe, 1979, 1989) differs from

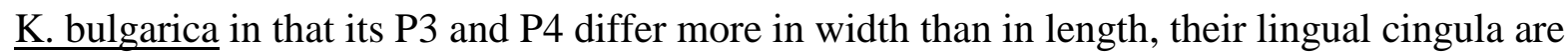
weak, its molars are broader than long, with a reduced second lobe and a posterior ectoloph which is oriented almost transversely.

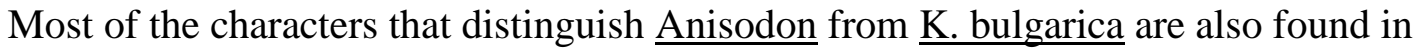
C. brevirostris from Tung Gur (AMNH 26518), except that the temporal fossa of the latter is long. A further difference is that the orbit is low and rounded at Tung Gur, instead of square at Kalimantsi. 
Finally, the Dytiko skull (DKO 234), holotype of "M." macedonicum, shares a number of similarities with the one from Kalimantsi: the muzzle is shortened (more so at Dytiko), the orbit is square, the cerebral skull is rather long (more so at Kalimantsi), there is a sagittal crest, the protoloph is short on the molars, $\mathrm{P} 4$ is not much broader than P3. We refrain from including both species in the same genus because of the very peculiar long molars at Kalimantsi, but they are possibly related.

This raises the problem of the relationships between "․․" macedonicum and Anisodon, all included in the same genus Macrotherium by Bonis \& al. (1995). After examination of the re-discovered Sansan skull, we think it impossible to hold their opinion, since several of the most important characters put forward to support the monophyly of "Macrotherium" no longer stand. These characters (Bonis et al., 1995: 160-161 and fig.8) were: high skull, very short face, nasal very short, high zygomatic arch, inflated braincase. However:

- the cerebral skull is in fact much lower in A. grande of Sansan (MNHNP) and Neudorf (Zapfe, 1979, fig.33) than at Dytiko;

- the face is in fact very long in $\underline{\text { A. grande, }}$, both at Sansan (MNHNP) and Neudorf (Zapfe, 1979: fig.34);

- the nasal is unknown at Neudorf, and not distinct from the frontal on the Sansan skull, but most unlikely to have been much reduced;

- the fragment of zygomatic arch figured by Blainville (1849) is now missing, but it is low at Neudorf (Zapfe, 1979, fig.34);

- the braincase is in fact quite narrow at Sansan.

We do not believe that the relationships of Miocene Chalicotheriinae can be satisfactorily solved by phylogenetic parsimonious analysis at the present time, because too few reasonably complete skulls are known, but two groups can be recognized: 
1) Chalicotheriinae with a low and broad cerebral skull, large facial skull, low rounded orbit, upper teeth with vestigial protoloph and protocone of moderate size. They would include

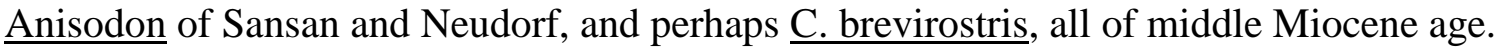
2) Chalicotheriinae with a high cerebral skull, reduced facial skull, high square orbit, upper teeth without protoloph. They would include $\underline{\text { K. bulgarica, and perhaps "M." macedonicum }}$ from Dytiko, of upper Miocene age. Only the discovery of cranial material would reveal the

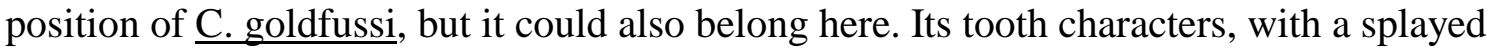
protocone separated from the hypocone by a wide valley, are more like those of $\underline{\mathrm{K}}$. bulgarica than are those of Anisodon, and both upper Miocene taxa might share a common ancestor, perhaps similar to the specimen from Nikolsburg (Abel, 1922: fig.108).

Thus, of the three genera listed below, the third one may be heterogeneous:

$\underline{\text { Anisodon }}$

Type-species

Type-locality

Sansan

Other localities

of the genus
A. grande (Blainville, 1849)

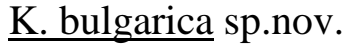

Kalimantsi-Pehtsata

C. goldfussi Kaup, 1833

Eppelsheim

La Grive ?

Dytiko ?
Chalicotherium

\section{Chalicotherium ? sp., cf Chalicotherium goldfussi Kaup, 1833}

This species is represented only by limb bones, all from Hadjidimovo-1.

The best specimen is a complete left manus (Fig.6A-C), but all bones are mounted together with plaster, and few details are visible. All bones are numbered separately, but we will refer to them as HD-650.

HD-650 certainly does not belong to Ancylotherium (the manus of which was described by Schaub, 1943), but differs by only a few details from the specimens from Neudorf described and illustrated by Zapfe (1979) as Chalicotherium grande, or from the material from 
Sansan (MNHNP). Among the latter is a set of metacarpals and phalanges (Sa 9349)

associated on a plaster socket so as to make up a complete manus, but only the metacarpals are probably of a single individual.

The main differences between HD-650 and Anisodon grande are the following. Length measurements are near or below the lower limit for $\underline{\text { A. grande, }}$ although other measurements are within the range for this species. The hand was therefore slightly shorter but more stout. The relative length of the metacarpals is also different. The hand from Sansan is close to the average of Neudorf, with Mc IV only slightly longer than Mc III, but the difference in length between these metacarpals is greater on HD-650 (and certainly beyond measurement error). It is therefore likely that the lengthening of Mc IV in this group of Chalicotheriinae is not, as Zapfe (1979: 182) surmised, a holdover of an ancient specialization, but rather an evolutionary trend.

A second conspicuous difference is the much greater size of the sesamoid bones in HD650. Indeed, the difference with A. grande (Zapfe, 1979: fig.105) is so great that one may suspect that the latter were not correctly identified (in contrast to Hadjidimovo, the Neudorf material comes from many different individuals).

It is again on digit IV that the phalanges differ from those of Neudorf: the first phalanx is rather short, but the second and third ones are transversely thicker. It is hard to interpret these differences functionally, but there is no doubt that, if the Hadjidimovo chalicothere is descended from $\underline{\text { A. grande, }}$ some functional evolution took place in the manus.

There are additional phalanges and distal metapodials from Hadjidimovo.

HD-663 is a first phalanx, perhaps digit II of the manus; the difference in width between the proximal and distal extremity is very great. There are also two distal ends of metacarpals, HD-666 (Mc II; sus-articular width 56.2) and HD-665 (Mc IV; sus-articular width 57.4). 
It is surprising that, although its limb bones are more common than those of Ancylotherium, no Chalicotherium teeth have been found in Hadjidimovo-1. This absence seriously hampers precise identification of the known material. The only possible comparison is with A. grande from Sansan and Neudorf, but the taxonomic significance of the observed differences is unknown. They might be as well of sub-specific as of generic value. Unfortunately, Schaefer and Zapfe (1971) did not describe the hand of $\underline{\text {. goldfussi, }}$, and that of $\underline{K}$. bulgarica is unknown, so that the identification that we propose is therefore rather speculative.

\section{Sub-family Schizotheriinae}

\section{Ancylotherium pentelicum (Gaudry and Lartet, 1856)}

Referred specimens--From Kalimantsi: K608, astragalus. From Hadjidimovo-1: All cranial and dental remains of Chalicotheriidae from Hadjidimovo-1 belong to this species. These are: 1) an incomplete juvenile skull, dorso-ventrally crushed, without occipital area, with DP2-M1, and M2 just piercing the maxilla, HD-633 (Fig.7B-C); 2) a series DP2-DP4, HD-634, little worn (Fig.7A); 3) a series M1-M2 plus a fragment of DP4, HD-635, little worn; and 4) an isolated DP2. Therefore, all specimens are from juvenile individuals. There are neither adult premolars, nor lower teeth.

\section{1) Material from Kalimantsi}

Bakalov (1955) and Bakalov and Nikolov (1962) described and illustrated A. pentelicum from Kalimantsi, in levels probably similar to that of Kalimantsi-Pehtsata. There is no doubt that their identifications are correct.

Two upper teeth from locality 1 of Kalimantsi, perhaps of Vallesian age (Nikolov, 1985) were described by Nikolov (1972) as Metaschizotherium von Koenigswald, 1932, a taxon 
from the Middle Miocene of Germany, often taken as a basal sub-genus of Ancylotherium (Thenius, 1953; Coombs, 1974, and pers.com.). The figures are unclear, and we could not find the teeth in Sofia, but the purported M3 is quite small, and its outline is that of a DP3. It could be a DP3 of Ancylotherium pentelicum.

The right astragalus K608 (Fig.2D-E) displays the typical chalicotheriid loss of the neck (Coombs, 1979). It is much more like that of Ancylotherium (Zapfe, 1979: fig.121; Guérin, 1987: fig.9.1.B) or Metaschizotherium (von Koenigswald, 1932: pl.3, fig.27-29) than like that of the chalicotherine Anisodon (Zapfe, 1979: fig.119-120, and our observations on the Sansan material) by the following features: 1) the lateral condyle is only slightly higher than the medial one; 2) there is no cuboid facet; 3) the ectal calcaneal facet is transversely elongated, its distal part is rather cylindrical; and 4) the sustentacular facet is much smaller than the ectal facet. Thus, it probably belongs to a Schizotheriinae, rather than to Kalimantsia.

\section{Measurements:}

Maximum width $=102.5$; height, perpendicular to distal facet $=62.5$; max. antero-posterior depth $=67 ;$ navicular facet: width $=74$, depth $=45$

Several specimens referred to $\underline{\mathrm{A}}$. pentelicum are not so high, and have a shallower groove of the trochlea and more asymmetrical condyles. Examples of this type are the astragalus figured by Zapfe (1979, fig.121), or an unpublished one from Ayas-Sehlek in the Maden Tetkik ve Arama, Ankara, Turkey. However, other specimens are more similar to K608. These are, e.g., astragali of A. pentelicum from Pikermi in the Natural History Museum of London (M.Coombs, pers.com.) or an astragalus from the Vallesian of Los Valles de Fuentidueña (Spain) described as Ancylotherium aff. A. pentelicum by Alberdi et al. (1981). It may be, therefore, that K608 is within the range of morphological variation of A.pentelicum, and we refer it provisionally to this species. 
2) Material from Hadjidimovo-1

Skull--The skull HD-633 (Fig.7B-C)is ontogenetically younger than the only previously published specimen of this species, from Titov Veles in Macedonia (Garevski, 1974), but is very similar and only a little smaller. The muzzle is long, with the anterior border of orbit behind M1 (and presumably still more posterior in the adult). The palate is relatively narrow, and of constant width from DP2 to M1. There is no preorbital fossa, nor any bony septum dividing the choanae, but there is a median keel on the basisphenoid. Supra-orbital width is approximately equal to bizygomatic width. The temporal lines are weak and gently convergent posteriorly, but they do not meet. A weak rough semi-circular line, anteriorly concave, runs across the posterior part of the frontals, behind their area of maximum breadth. Except for this line, not visible on Garevski's figures, all features of HD-633 match those of the Titov Veles specimen.

The skull is quite different from that of the Chalicotheriinae and need only be compared to the Schizotheriinae.

Compared with those of Moropus (Coombs, 1978, fig.3) or Tylocephalonyx (Coombs, 1979, fig.6), the muzzle is certainly more reduced, at least dorso-ventrally, and the frontal certainly lacked the high hump of the latter genus. In dorsal view, the skull is sharply distinct from that of Moropus (Holland \& Petterson, 1914, pl. 48). The latter is not so broad behind the orbits, its temporal lines are strongly marked, converge immediately behind the supraorbital processes, and fuse on the median line into a sagittal crest.

Milk premolars--They were previously unknown (a few teeth from Samos in the AMNH have never been published - M.Coombs, pers.com.). DP2 is much longer than broad (Fig.7A). It is almost completely circled, except around the parastyle, by a cingular ridge. The protoloph is posterolingually oblique, and the protocone is stretched mesiodistally along the lingual margin, even reaching the base of the hypocone, thus closing the median valley. The hypocone 
is much stronger and higher than the protocone. It is connected to the ectoloph by an intermediate tubercle rather than by a true metaloph. Both Moropus and Tylocephalonyx have shorter DP2s, with a transverse protoloph (Coombs, 1978, fig. 6D; 1979, fig. 5A-B).

DP3 and DP4 are more similar to permanent molars. They are more elongated than in Tylocephalonyx, and still more so than in Moropus. The first lobe is longer than the second one on DP3, but they are sub-equal on DP4, as on the molars, and as in Tylocephalonyx. In

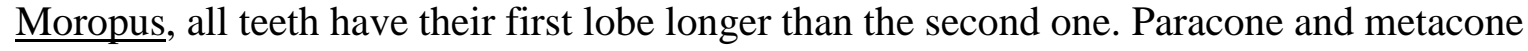
ribs are clearly visible, although weak, not unlike $\underline{\text { Moropus, }}$ although the latter has no metacone rib. Styles are very salient, especially the mesostyle, which is much more strongly pinched than in Moropus.

There is a small protoconule demarcated from the paracone but, lingually, the protoloph is nothing more than a very low crest; it meets another low crest rising from the lingual cingulum to the tip of the protocone. The latter is a strong conical tubercle, about as high as (DP3) or slightly higher than (DP4) the hypocone.

The hypocone is lower than the metaloph, but becomes higher through wear of the latter. A ridge descending from its tip to the postero-labial corner of the tooth borders a postfossette, which remains postero-labially open. There is a weak labial cingulum, at least on DP3, and a strong lingual one, from the parastyle to the base of the hypocone. The labial wall of DP4 is about as high as the tooth is broad; thus this tooth is relatively as hypsodont as M2.

Molars--M1 and M2 are similar to the DP4. The mesostyle is more pinched. There is a weak paracone rib, but none on the metacone. The protoloph is very short, and lacks any crest on the protocone. On the latter, the crest descending from its tip to the cingulum is more ridge-like, and the protocone less regularly conical than on DP4. There is a strong crochet on the M1 and M2 of HD-635, but none on HD-633. The posterior crest descending from the 
hypocone is weaker than on the milk-teeth, or than in the M2 illustrated by Thenius (1953, fig.1).

The molars of Ancylotherium greatly differ from those of Moropus by the length of the second lobe, much stronger styles, greater concavity of the ectoloph, shortness of the protoloph, and strength of the lingual cingulum. They are much more like those of Tylocephalonyx, but the latter has no ectoloph ribs, the protoloph may be longer (Coombs, 1979, Fig.3 and 5) and, seemingly, the styles were less pinched and the cingulum weaker. There is no doubt, however, as noted by Coombs (1979) that the teeth of Tylocephalonyx are close to those of Ancylotherium (even though the latter sometimes bear a crochet), and generic distinction would probably not be justified on the basis of teeth alone.

Post-cranials--HD-660 and HD-664 are proximal anterior phalanges of Ancylotherium, easily distinguished from those of the Chalicotheriinae by the orientation of the proximal facet. They are much more slender ( Table 4) than that of digit IV (Schaub, 1943, fig.22) and must belong to digit III. HD-662 is an incomplete duplex of digit II.

\section{CONCLUSIONS}

It is widely acknowledged that Chalicotheriinae and Schizotheriinae had different ecological requirements (Coombs, 1989; Bonis et al., 1999). In middle Miocene times, both subfamilies range through present-day Europe, from Iberia (Antunes, 1966; Belinchon and Montoya, 1990; Villalta and Crusafont, 1945) to Turkey (Fortelius, 1990; Kaya, 1993). Ecological segregation became probably established by late Miocene times. There is little doubt that increased hypsodonty made Ancylotherium better fitted than its forerunner Metaschizotherium to the more open landscapes that became predominant in the Aegean area at that time. On the contrary, Chalicotheriinae are usually associated with forest-dwelling mammals, especially tragulids and tapirs, as demonstrated by Bonis et al. (1999). Probably 
because of this ecological specialisation, they remained rather conservative in tooth morphology, but this did not prevent them from evolving sharp changes in skull proportions, the functional meaning of which remain poorly undertsood.

Bonis et al. (1999) regarded the few reported associations of Schizotheriinae and Chalicotheriinae as doubtful, and probably due to a mixing of localities. There are, however, a few sites in the Balkans where both groups seem to co-occur. Titov Veles in Macedonia might be one of them, if the Ancylotherium and Chalicotherium described from there (Garevski and Zapfe, 1983) come from the same locality. In Bulgaria, both groups have also been reported from Gorna Sushitsa (Bakalov, 1955; Nikolov, 1975), where a single locality is known, but they were collected at a 20 years interval, and it is hard to be sure that they really come from the same spot. At Kalimantsi, co-occurrence is likely but not demonstrated because of the existence of several localities. On the contrary, Hadjidimovo-1 is a single locality, and coexistence there is not in doubt. Thus, both groups were not so mutually exclusive as Bonis et al. (1999) thought, although they certainly exploited different parts of the vegetation. An ecological parallel can perhaps be found among giraffids, with the rather high-crowned $\underline{\text { Helladotherium }}$ or Samotherium co-occurring in several sites of the same area with the leafeating Bohlinia (Bonis et al., 1992).

\section{ACKNOWLEDGMENTS}

We are pleased to thank people who made fossils or casts available to us: B. Senut and P. Tassy (Muséum National d'Histoire Naturelle, Paris), and especially G. Bouvrain (Université Paris VI) and L. de Bonis (Université de Poitiers). We are also grateful to M. Coombs for her comments and many unpublished observations, and to two other reviewers for their most helpful corrections and remarks. 


\section{LITERATURE CITED}

Abel, 0. 1922. Lebensbilder ans der Tierwelt der Vorzeit. G.Fischer, Jena, 643pp.

Alberdi, M. T., L. Ginsburg, and J. Morales. 1981. Rhinocerotidae del yacimiento de los Valles de Fuentidueña (Segovia). Estudios geológicos 37:439-465.

Antunes, M. T. 1966. Notes sur la géologie et la paléontologie du Miocène de Lisbonne. V. Un schizotheriiné du genre Phylotillon (Chalicotherioidea, Perissodactyla) dans l'Helvétien V-b de Charneca do Lumiar. Remarques écologiques sur la faune de Mammifères. Boletin da Sociedade Geologica de Portugal 16:159-178.

Bakalov, P. 1955. Chalicotheriidae in Südwestbulgarien. Izvestija Geologiceskogo Instituta Bolgarskoj Akademii Nauk 3:151-159. [in Bulgarian, with German abstract]. , and I. Nikolov. 1962. Les Fossiles de Bulgarie. X. Mammifères Tertiaires.

Académie des Sciences de Bulgarie, Sofia, 162 pp.

Belinchon M. and P.Montoya. 1990. Presencia de Phyllotillon naricus PILGRIM, 1910

(Chalicotheriidae, Perissodactyla, Mammalia) en el Aragoniense de Buñol (Valencia). Breve síntesis de los calicotéridos en el registro español. Paleontología i Evolució 23:171-180.

Blainville, H. M. Ducrotay de 1837. Rapport sur un nouvel envoi de fossiles provenant du dépôt de Sansan. Comptes-Rendus de l'Académie des Sciences 5:417-427. 1849. Ostéographie ou description iconographique comparée du squelette et du système dentaire des Mammifères récents et fossiles pour servir de base à la zoologie et la géologie. Tome quatrième: Quaternatès Maldentés. Anoplotherium. Baillière, Paris, 155pp. 
Bonis, L.de, G. Bouvrain, D. Geraads and G. Koufos. 1992. Diversity and paleoecology of Greek late Miocene mammalian faunas. Palaeogeography, Palaeoclimatology, Palaeoecology 91:99-121.

Bonis, L.de, G. Bouvrain, G. Koufos, and P. Tassy. 1995. Un crâne de Chalicothère (Mammalia, Perissodactyla) du Miocène supérieur de Macédoine (Grèce): remarques sur la phylogénie des Chalicotheriinae. Palaeovertebrata 24:135-176.

Bonis, L.de, G. Bouvrain, and G. Koufos, 1999. Palaeoenvironments of late Miocene primate localities in Macedonia, Greece. In: Agustí, J., L.Rook, and P.Andrews, (eds), The Evolution of Neogene terrestrial Ecosystems in Europe. pp.415-435, Cambridge University Press.

Butler, P. M. 1965. East African Miocene and Pleistocene Chalicotheres. Bulletin of the British Museum (Natural History) Geology 10:163-237.

Colbert, E. H. 1934. Chalicotheres from Mongolia and China in the American Museum. Bulletin of the American Museum of Natural History 67:353-387.

Coombs, M. C. 1974. Ein Vertreter von Moropus aus dem euroipäischen Aquitanien und eine Zusammenfassung der europäischen postoligozänen Schizotheriinae (Mammalia, Perissodactyla, Chalicotheriidae). Sitzungsberichten der Österreich Akademie der Wissenschaften, Math.Nat. Klasse, I, 182:273-288.

1975. Sexual dimorphism in Chalicotheres. Systematic Zoology 24:55-62. 1978. Reevaluation of early Miocene North American Moropus (Perissodactyla,

Chalicotheriidae, Schizotheriinae). Bulletin of Carnegie Museum of Natural History $4: 1-62$ 1979. Tylocephalonyx, a new genus of North American dome-skulled Chalicotheres (Mammalia, Perissodactyla). Bulletin of the American Museum of Natural History 164:1-64. 
Depéret, C. 1892. La faune de mammifères miocènes de La Grive-Saint-Alban (Isère) et de quelques autres localités du bassin du Rhône. Archives du Muséum d'Histoire Naturelle de Lyon 5:1-93.

Fejfar, O., E. P. J. Heizmann and P. Major 1998. Metaschizotherium cf wetzleri (Kowalewsky) from the early Miocene of Czech Republik and South Germany. Mémoires et Travaux de l'E.P.H.E. 21:707-709.

Fortelius, M. 1990. Less common ungulate species from Pasalar, middle Miocene of Anatolia (Turkey). Journal of Human Evolution 19:479-487.

Garevski, R. 1974. Beitrag zur Kenntnis der Pikermifauna Mazedoniens. Fossilreste der Chalicotheriiden. Fragmenta Balcanica 9:201-209.

-, and Zapfe, H. 1983. Weitere Chalicotheriiden-Funde aus der Pikermi-Fauna von Titov Veles (Mazedonien, Jugoslawien). Acta Musei Macedonici Scientarum Naturalium 17:1-19.

Gaudry, A. and Lartet, E. 1856. Résultats des recherches paléontologiques entreprises dans l'Attique sous les auspices de l'Académie. Comptes-rendus hebdomadaires des séances de l'Académie des Sciences 43:271-274, and 43:318-321.

Heissig, K. 1998. Family Chalicotheriidae; pp.189-192 in Rössner G.E. and K.Heissig, The Miocene Land Mammals of Europe. F. Pfeil, München.

Holland, W. J. and O. A. Petterson. 1914. The osteology of the Chalicotherioidea with special reference to a mounted skeleton of Moropus elatus Marsh, now installed in the Carnegie Museum. Memoirs of Carnegie Museum 3:189-406.

Kaup, J. J. 1833. Descriptions d'ossemens fossiles de mammifères inconnus jusqu'à présent qui se trouvent au Muséum grand-ducal de Darmstadt. Second cahier, pp. 1-31, pls. VI-IX. Heyer, Darmstadt. 
Kaya, T. 1993. First record of Moropus elatus (Chalicotheriidae-Perissodactyla) in Turkey (Seyitömer-Kütahya). Turkish Journal of Earth Sciences 2:189-194.

Koenigswald, G. H. R. von. 1932. Metaschizotherium fraasi n. g. n. sp., ein neuer

Chalicotheriide ans dem Obermiozän von Steinheim a. Albuch. (Die tertiären Wirbeltiere des Steinheimer Beckens VIII). Palaeontographica, Suppl. Bd. 8:1-24.

Kojumdgieva, E., I. Nikolov, P. Nedjalkov and A. Busev. 1982. Stratigraphy of the Neogene in Sandanski Graben. Geologica Balcanica 12:69-81.

Kovachev, D. 1988. Indarctos bakalovi sp.n. (Ursidae) du Méotien près du village Kalimanci (Sud-Ouest de la Bulgarie). Review of the Bulgarian Geological Society 49:65-73.

Kowalevsky, W. 1874. Monographie der Gattung Anthracotherium Cuv. Palaeontographica 22: $131-346$.

Lartet, E. 1851. Notice sur la colline de Sansan. 45pp., Auch.

Nikolov, I. 1972. [On the stratigraphic level of Metaschizotherium fraasi Koenigswald].

Bulgarian Academy of Sciences, Bulletin of the Geological Institute, Series Paleontology 21:129-131 [in Bulgarian]. 1975. Neue Fossilienfunde von Familie Chalicotheriidae (Mammalia) aus Bulgarien. Review of the Bulgarian Geological Society 36:311-313. 1985. Catalogue of the localities of Tertiary Mammals in Bulgaria. Paleontology, Stratigraphy and Lithology (Sofia) 21:43-62.

Pictet, F.-J. 1844. Traité élémentaire de Paléontologie. 371pp, Genève.

Schaefer, H. and H. Zapfe. 1971. Chalicotherium grande BLAINV. und Chalicotherium goldfussi KAUP. Odontologische und osteologische Unterschiede. Verhandlungen der Naturforschenden Gesellschaft in Basel 81:157-199.

Schaub, S. 1943. Die Vorderextremität von Ancylotherium pentelicum GAUDRY und LARTET. Schweizerisches Paläontologische Abhandlungen 64:1-36. 
Spassov, N. 1999. The new paleontological museum in Assenovgrad (a branch of the

N.M.N.H., Sofia) and its importance for the investigations of the Hipparion-fauna in SE-Europe. Europal 14: 18-19.

. In press. Late Miocene to Pliocene large Mammal faunal succession in Bulgaria. Biochronology and evolution of paleoenvironments. Special volume in Honour of A.Azzaroli, University of Florence.

Symeonidis, N. K. 1973. Chalicotherium goldfussi KAUP (Perissodactyla, Mammalia) aus dem Altpliozän von Pikermi (Griechenland). Annales Géologiques des Pays Helléniques 25:301-307.

Thenius, E. 1953. Das Maxillargebiss von Ancylotherium pentelicum GAUDRY und LARTET. Annales Géologiques des Pays Helléniques 5:97-106.

Tzankov, T., N. Spassov and G. Nikolov. 1999. [On the character of the Upper Paleogene and Neogene relief and landscape evolution in S-W Bulgaria]. In: Investigations on the Geodynamic in relation to the Earthquake of Krupnik - Kresna, 1904. Blagoevgrad 27 - 28 April, 1999. Proceedings of papers. Bulgarian Academy of Sciences, Blagoevgrad, pp. 85-94 [in Bulgarian].

Villalta, J. F. and M. Crusafont. 1945. Los vertebrados del Mioceno continental de la cuenca del Vallés-Penedés (provincia de Barcelona). III. Ungulados: A. Perisodáctilos. I. Chalicotheriinae. Estudios geológicos 1:111-167.

Zapfe, H. 1979. Chalicotherium grande (BLAINV.) aus dem miozänen Spaltenfüllung von Neudorf an der March (Devinska Nová Ves), Tschechoslowakei. Neue Denkschriften des naturhistorisches Museums in Wien 2:1-282.

Zapfe, H. 1989. Chalicotherium goldfussi KAUP aus dem Vallesien vom Höwenegg im Hegau (Südwestdeutschland). Andrias 6:117-126. 
TABLE 1 - Skull measurements of Chalicotheriinae

$\begin{array}{ccccc}\text { Kalimantsia } & \text { C.brevirostris } & \text { Dytiko } & \text { La Grive } & \text { Sansan } \\ \text { K631 } & \text { AMNH 26518 } & \text { DKO 234 } & \text { Lgr 1065 } & \text { MNHNP } \\ & \text { cast } & \text { cast } & \text { cast } & \end{array}$

$\begin{array}{lccccc}\text { Length, front of P2 to occ.condyle } & \pm 390 & 387 & \pm 310 & \pm 430 & 320 ? \\ \text { Length, front of orbit to occ.crest } & 285 & \pm 285 & \pm 240 & - & \pm 200 \\ \text { Length, from orbit to fo.infra-orbitale } & 43 & 42 & \pm 37 & - & 55+ \\ \text { Length, orbit to front of P2 } & \pm 100 & \pm 122 & \pm 101 & - & \pm 120 \\ \text { Length, P2 to proc.post-glenoides } & - & 295 & \pm 230 & \pm 325 & \pm 230 \\ \text { Length, M3 to ditto } & - & 145 & \pm 100 & \pm 150 & \pm 95 \\ \text { Length M1-M3 } & 113 & 105 & 102 & \pm 120 & 97 \\ \text { Length, M1 to occ.condyle } & 345 ? & 335 & 275 & \pm 360 & \pm 250 \\ \text { Length, M1 to proc.post-glenoides } & - & \pm 253 & \pm 200 & \pm 270 & 200 \\ \text { Max.bizygomatic width } & - & 248 & 230 ? & \pm 280 & - \\ \text { Bizygomatic width above M3 } & - & 215 & 200 ? & - & 200 \\ \text { Width over mastoid processes } & - & 175 & 172 & 215 & 170 \\ \text { Length, orbit to proc.post-glenoides } & 210+ & 188 & 152 ? & 200+ & 125 \\ \text { Palatal width between M3 } & - & 77 & - & - & 75 \\ \text { Occip. height, from base of condyles } & - & - & 121 & 150+ & 100 ?\end{array}$


TABLE 2 - Comparative measurements of the metacarpals and phalanges of HD-650 from Hadjidimovo with those of Anisodon grande (Neudorf, from Zapfe, 1979; Sansan Sa 9349 in MNHNP)

MC II $\quad$ MC III MC IV

\section{HD-650 Neudorf Sansan HD-650 Neudorf Sansan HD-650 Neudorf Sansan}

\begin{tabular}{lccccccccc} 
Max. length & \pm 140 & $146-171$ & 164 & \pm 165 & $168-213$ & 200 & \pm 183 & $176-226$ & 206 \\
Proximal, A-P & 74 & $63-82$ & 68 & 51 & $44-57$ & 50 & $60+$ & $45-61$ & 51.5 \\
Sus-artic.width, distal & 46.5 & $42-55$ & 53.7 & 37 & $36-49$ & 39.5 & $40+$ & $48-59$ & 41.5 \\
\multicolumn{2}{l}{ Distal artic.width } & 50 & & 54 & 45.5 & & 48.5 & 50 &
\end{tabular}

Digit II DigIT III DigIT IV

HD-650 HD-663 Neudorf HD-650 Neudorf HD-650 Neudorf

FIRST PHALANX

$\begin{array}{lccccccc}\text { Max.length } & 68.5 & 83.7 & 65-78 & 71 & 72-87 & 59 & 64-81 \\ \text { Max.prox.width } & 53 & 61.8 & 42-56 & 55 & 46-58 & 46.2 & 45-54 \\ \text { SECOND PHALANX } & & & & & & & \\ \text { Max.width } & 33.5 & & 31.5-39 & 37 & 28-35 & 36 & 23.6-34 \\ \begin{array}{l}\text { Depth distal artic. } \\ \text { THIRD PHALANX }\end{array} & 41.6 & 43-52 & 45.5 & 46.2-53.5 & 40.2 & 40-47 \\ \text { Height } & 70 & & 64-75 & 73 & 67-82 & 66 & 58-71 \\ \text { Width } & 30 & 31-34 & 32.3 & 28-36 & 34.7 & 23-31\end{array}$


TABLE 3 - Tooth measurements of Ancylotherium pentelicum from Hadjidimovo-1 (length x width in mm); height of unworn metacone in brackets.

$\begin{array}{ccccc}\text { DP2 } & \text { DP3 } & \text { DP4 } & \text { M1 } & \text { M2 } \\ 26.9 \times 20.8 & 30.1 \times 26.4 & 39.8 \times 32.9 & 53.2 \times 43.0 & \\ 24.3 \times 19.2 & 29.2 \times 25.9 & 36.3 \times 30.9(32) & & \\ & & -\times 35 & 49.4 \times 42.8 & 60.7 \times 51.3(49)\end{array}$


TABLE 4 - Measurements of proximal phalanges of Ancylotherium

Max.length Prox.width $\quad \begin{aligned} & \text { Distal width, } \\ & \text { sus-articular }\end{aligned}$ A-P length

$\begin{array}{ccccc}\text { HD-660 } & 90 & 49 & 36.5 & 35 \\ \text { HD-664 } & 94 & 56 & 37.3 & 35 \\ \text { HD-662 } & 112.5(1 \text { st phal. }) & 57 & 52.3 & 42\end{array}$


Captions to figures 1-7

FIGURE 1. Map of Bulgaria, with the position of the two main localities discussed in the text.

FIGURE 2. Kalimantsia bulgarica, holotype skull K-631, from Kalimantsi-Pehtsata. A, dorsal view. B, lateral view. Scale $=100 \mathrm{~mm}$.

FIGURE 3. A-C, Kalimantsia bulgarica, holotype, from Kalimantsi-Pehtsata. A, stereo view of right P4. B, stereo view of right M2-M3. C, right tooth-row. D-E, Ancylotherium pentelicum ? from Kalimantsi-Pehtsata, astragalus. D, anterior view. E, distal view. Scale: 50mm for Fig.A, 75 mm for Fig.B, $150 \mathrm{~mm}$ for Fig.C, $125 \mathrm{~mm}$ for Fig.D-E.

FIGURE 4. Length $\mathrm{x}$ width scatterplot of chalicotheriine P3 and P4. P4 is always larger than P3, but only at Kalimantsi is the difference in length much greater than the difference in width. Neudorf, from Zapfe (1979); Chomateri (Pikermi) from Symeonidis (1973)

FIGURE 5. Length $\mathrm{x}$ width scatterplot of chalicotheriine molars. Only specimens where all three molars can be measured are shown. M1, M2 and M3 increase in size in this order.

FIGURE 6. Chalicotherium cf goldfussi from Hadjidimovo-1, left manus HD-650 in (A) medial, (B) anterior and (C) lateral views.

FIGURE 7. Ancylotherium pentelicum from Hadjidimovo-1. A, Stereo view of DP2-DP4 HD-634. B, skull HD-633 in (B) dorsal and (C) ventral views. Scale: $50 \mathrm{~mm}$ for A, $150 \mathrm{~mm}$ for B-C. 